\title{
Effects of the level and duration of maternal diets with negative dietary cation-anion differences prepartum on calf growth, immunity, and mineral and energy metabolism
}

\author{
C. Collazos, C. Lopera, J. E. P. Santos, and J. Laporta ${ }^{1}$ \\ Department of Animal Sciences, University of Florida, Gainesville 32611
}

\begin{abstract}
The objectives were to investigate the effects that maternal diets containing negative dietary cation-anion differences (DCAD) fed in the last $42 \mathrm{~d}$ of gestation may have on the acid-base status, hematology, mineral and energy metabolism, growth, and health of calves. The experiment was a randomized block design with a $2 \times 2$ factorial arrangement of 2 levels of negative DCAD ( -70 or $-180 \mathrm{mEq} / \mathrm{kg}$ ) and 2 feeding durations (the last $21 \mathrm{~d}$ prepartum and the last $42 \mathrm{~d}$ prepartum). Bulls and heifers $(n=60)$ born to these dams were weighted at birth and fed $3.8 \mathrm{~L}$ of colostrum for their first feeding, and only heifers $(\mathrm{n}=44,9-12$ /treatment) were kept thereafter. Heifer body weight was also recorded at $21 \mathrm{~d}, 42 \mathrm{~d}, 62 \mathrm{~d}, 3 \mathrm{mo}$, and $6 \mathrm{mo}$ of age. Blood was collected at birth, before colostrum feeding, and at 1,2, 3, 21, and $42 \mathrm{~d}$ of age and assayed for minerals, metabolites, and cell counts. Heifers born to dams fed the last $42 \mathrm{~d}$ prepartum weighed 2.8 and $4.8 \mathrm{~kg}$ less at birth and $62 \mathrm{~d}$, respectively, compared with calves born to dams fed the last $21 \mathrm{~d}$ prepartum; however, body weight at 3 and 6 mo of age was similar. Concentrations of ionized calcium did not differ among treatments at birth, but heifers born to -180 DCAD dams had increased blood concentrations at $3 \mathrm{~d}$ of age, whereas those born to -70 DCAD dams did not. At birth, heifers born to -180 DCAD dams experienced a subtle and transient metabolic acidosis $(\mathrm{pH}=7.33 \pm$ $0.02 ; \mathrm{pCO}_{2}=53.0 \pm 2.4 \mathrm{mmHg} ; \mathrm{HCO}_{3}^{-}=27.6 \pm 0.7$ $\mathrm{mmol} / \mathrm{L}$ ) compared with the more evident metabolic acidosis observed in those born to -70 DCAD cows $\left(\mathrm{pH}=7.28 \pm 0.02 ; \mathrm{pCO}_{2}=59.3 \pm 2.4 \mathrm{mmHg} ; \mathrm{HCO}_{3}{ }^{-}\right.$ $=27.8 \pm 0.7 \mathrm{mmol} / \mathrm{L})$. Heifers born to $-180 \mathrm{DCAD}$ dams had reduced concentrations of $\beta$-hydroxybutric acid and nonesterified fatty acids compared with those born to -70 DCAD dams. Efficiency of IgG transfer
\end{abstract}

Received May 19, 2017.

Accepted August 21, 2017.

${ }^{1}$ Corresponding author: jlaporta@ufl.edu from colostrum into blood and serum concentrations did not differ among treatments. There was no relationship between measures of metabolic acidosis and measures of efficiency of IgG absorption. Percentage of lymphocytes and neutrophils was altered by maternal treatments; however, treatments did not affect calf morbidity. Extending the duration of feeding up to $42 \mathrm{~d}$ or reducing the level of negative DCAD to $-180 \mathrm{mEq} / \mathrm{kg}$ in maternal diets exerted a transient metabolic acidosis in the calves and slightly affected measures of mineral, energy metabolism, and growth.

Key words: acid-base balance, dairy calf, immunoglobulin G, maternal dietary cation-anion difference

\section{INTRODUCTION}

Approximately $25 \%$ of periparturient primiparous cows and $50 \%$ of periparturient multiparous cows on dairy farms in the United States suffer from subclinical hypocalcemia, and 5 to $7 \%$ of cows develop clinical hypocalcemia (Reinhardt et al., 2011). Hypocalcemia is a metabolic disorder that occurs when there are reduced circulating concentrations of calcium $(\mathrm{Ca})$ in the blood. Risk factors for hypocalcemia in dairy cows include age and breed of cow and diets with high $\mathrm{K}$ and $\mathrm{Na}$ content, among others, which may lead to other metabolic disorders and diseases such as mastitis and reduced rumen and abomasal contractions (Huber et al., 1981; Curtis et al., 1983). Approximately $30 \%$ of dairy farms across the United States implement prepartum diets with negative DCAD to reduce the incidence of hypocalcemia at the onset of lactation (NAHMS, 2014). The typical recommendation is to feed a diet with negative DCAD, from -50 to $-100 \mathrm{mEq} / \mathrm{kg}$, during the last 21 d prepartum. In some situations dairy producers might prefer a single prepartum diet, which would result in feeding dairy cows a diet with a negative DCAD for more than $21 \mathrm{~d}$ prepartum. Although the optimum DCAD prepartum for cows remains unknown, even less is known about the effect on newborns. It is known that nutrient manipulations during the third trimester 
of gestation can influence fetal and postnatal development of the offspring (Corah et al., 1975; Du et al., 2010; Gao et al., 2012). A diet with a negative DCAD prepartum induces a compensated metabolic acidosis in dairy cows, which decreases the cows' blood $\mathrm{pH}$ and has been shown to increase blood Ca concentrations (Oetzel, 1988). However, the effects that acidogenic diets fed to dairy cows during late gestation may have on the developing offspring have been less studied.

Acidosis in neonates can occur as the result of dystocia and hypoxia during delivery (Quigley and Baum, 2004). Moreover, postnatal respiratory or metabolic acidosis has been linked to reduced colostral Ig absorption, leading to increased risk of mortality in dairy calves (Besser and Gay, 1994). It is possible that maternal metabolic acidosis induced by feeding acidogenic diets to dams prepartum could affect the neonate in utero because of the highly vascularized nutrient transfer system that occurs during the last trimester. Limited research has explored whether the induced maternal compensated metabolic acidosis might influence the physiology of the calf postnatally. Morrill et al. (2010) found that the efficiency of absorption and the concentrations of Ig in calves born to dams fed a diet with a DCAD of $-100 \mathrm{mEq} / \mathrm{kg}$ did not differ from that of calves born to dams fed a diet with a DCAD of $+77 \mathrm{mEq} / \mathrm{kg}$ during the last $21 \mathrm{~d}$ prepartum. Weich et al. (2013) reported that reducing the DCAD from +120 to $-160 \mathrm{mEq} / \mathrm{kg}$ or extending the feeding of $-160 \mathrm{mEq} / \mathrm{kg}$ from 21 to 42 $\mathrm{d}$ prepartum did not influence colostrum yield or calf birth BW. The effect that negative DCAD exerts on the cow's mineral metabolism and acid-base balance has been reported extensively (Horst et al., 1997; Charbonneau et al., 2006; Goff, 2008); however, reducing the DCAD by feeding more acidogenic diets prepartum might affect acid-base status of calves and influence postnatal performance.

The objectives of this experiment were to evaluate the effects of extending the dam's feeding duration, from 21 to $42 \mathrm{~d}$, and reducing the level of negative DCAD prepartum, from -70 or $-180 \mathrm{mEq} / \mathrm{kg}$, on the acid-base balance, mineral and energy metabolism, and performance of the offspring postnatally. We hypothesized that growth, immunity, and morbidity would not be greatly affected, whereas acid-base balance and energy and mineral metabolism could be affected by the maternal DCAD treatment manipulations.

\section{MATERIALS AND METHODS}

\section{Animals and Experimental Design}

Animal procedures were approved by the University of Florida Institutional Animal Care and Use Commit- tee. The experiment was conducted from January to June 2016 at the Dairy and Calf Research Units of the University of Florida (Alachua, FL). The experiment was a randomized block design with a $2 \times 2$ factorial arrangement of treatments. Weekly cohorts of parous cows were blocked by parity and 305-d milk yield. Within each block they were randomly assigned to 1 of 4 treatments with 2 levels of negative DCAD $(-70$ or $-180 \mathrm{mEq} / \mathrm{kg}$ ) fed for 2 durations [the last $21 \mathrm{~d}$ of gestation, designated as short $(\mathbf{S})$, or the last $42 \mathrm{~d}$ of gestation, designated as long $(\mathbf{L})]$.

\section{Cows, Housing, and Prepartum Diets}

Dams at $230 \pm 3 \mathrm{~d}$ of gestation were moved to a barn with individual feeding gates for treatment administration. Cows were trained for $2 \mathrm{~d}$ before treatments started. A description of the diets is presented in Table 1. Cows in the $\mathrm{S}$ group were fed a diet with positive DCAD from $232 \pm 3$ to $255 \mathrm{~d}$ of gestation, and then they were switched to diets containing negative DCAD starting at $255 \mathrm{~d}$ of gestation until calving. Cows in the $\mathrm{L}$ group were fed the respective negative DCAD treatments from $232 \pm 3 \mathrm{~d}$ of gestation to calving. Diets were isonitrogenous and isocaloric and were formulated to differ in the concentrations of strong ions to manipulate the DCAD to achieve -70 or $-180 \mathrm{mEq} /$ $\mathrm{kg}$. Samples of forages and concentrates were collected weekly and analyzed for their chemical composition to ensure desired negative DCAD levels. Details of diet sampling and analyses are presented elsewhere (Lopera et al., 2016). Briefly, samples of individual ingredients were collected weekly, processed, and composited into 5 monthly samples that were subjected to chemical analyses.

\section{Calf Management}

Calves born to dams fed the $-70 \mathrm{~S}(\mathrm{n}=9$ heifers and 5 bulls), $-70 \mathrm{~L}$ ( $\mathrm{n}=12$ heifers and 3 bulls), $-180 \mathrm{~L}$ ( $\mathrm{n}=11$ heifers and 4 bulls), or $-180 \mathrm{~S}$ ( $\mathrm{n}=12$ heifers and 4 bulls) diets were used in the experiment. Twins and stillbirths were not included, and 1 dystocia case occurred. Gestation length of dams was calculated, and BW of all calves was recorded at birth. Day of birth was considered experiment d 0 . Calves were separated from their dams, had their navels dipped with $2 \%$ iodine to prevent infection, and were fed $3.8 \mathrm{~L}$ of colostrum. Calves were fed pool colostrum from the farm, and samples were collected 3 times per week and placed at $-20^{\circ} \mathrm{C}$ until analysis. All calves were transported to the University of Florida Calf Unit and housed in individual hutches, and calves received ad libitum calf starter grain (Ampli-Calf Starter 20, Purina Animal Nutrition LLC, 
Table 1. Ingredient composition and nutrient profile of diets fed to cows prepartum

\begin{tabular}{|c|c|c|c|}
\hline Item & Positive DCAD & $-70 \mathrm{mEq} / \mathrm{kg}$ & $-180 \mathrm{mEq} / \mathrm{kg}$ \\
\hline \multicolumn{4}{|l|}{ Ingredient ( $\%$ of $\mathrm{DM})$} \\
\hline Corn silage & 34.2 & 34.2 & 34.2 \\
\hline Triticale silage & 20.4 & 20.4 & 20.4 \\
\hline Bermuda hay & 6.7 & 6.7 & 6.7 \\
\hline Straw & 13.8 & 13.8 & 13.8 \\
\hline Citrus pulp & 7.7 & 7.1 & 6.7 \\
\hline Soybean meal & 13.1 & 8.5 & 5.8 \\
\hline Prepartum mineral $^{1}$ & 4.2 & 4.2 & 4.2 \\
\hline Acidogenic product ${ }^{2}$ & 0 & 5.2 & 8.3 \\
\hline \multicolumn{4}{|c|}{ Nutrient content $^{3}($ mean $\pm \mathrm{SD})$} \\
\hline $\mathrm{CP}(\%)$ & $14.9 \pm 0.8$ & $14.7 \pm 0.4$ & $14.6 \pm 0.6$ \\
\hline $\operatorname{ADF}(\%)$ & $29.4 \pm 1.4$ & $28.9 \pm 1.2$ & $29.1 \pm 1.1$ \\
\hline $\operatorname{NDF}(\%)$ & $43.1 \pm 1.7$ & $43.7 \pm 1.5$ & $43.8 \pm 1.5$ \\
\hline Forage NDF (\%) & $39.3 \pm 1.7$ & $39.3 \pm 1.7$ & $39.3 \pm 1.7$ \\
\hline $\operatorname{NFC}(\%)$ & $31.7 \pm 1.3$ & $31.1 \pm 1.6$ & $31.1 \pm 1.9$ \\
\hline Starch (\%) & $12.3 \pm 0.4$ & $12.6 \pm 0.5$ & $12.9 \pm 0.6$ \\
\hline Fat $(\%)$ & $2.8 \pm 0.2$ & $2.8 \pm 0.1$ & $2.8 \pm 0.1$ \\
\hline $\mathrm{Ca}(\%)$ & $0.67 \pm 0.07$ & $0.64 \pm 0.05$ & $0.62 \pm 0.05$ \\
\hline $\mathrm{P}(\%)$ & $0.33 \pm 0.01$ & $0.33 \pm 0.02$ & $0.33 \pm 0.03$ \\
\hline $\operatorname{Mg}(\%)$ & $0.44 \pm 0.06$ & $0.47 \pm 0.06$ & $0.48 \pm 0.03$ \\
\hline $\mathrm{K}(\%)$ & $1.54 \pm 0.10$ & $1.49 \pm 0.09$ & $1.46 \pm 0.09$ \\
\hline $\mathrm{S}(\%)$ & $0.29 \pm 0.03$ & $0.40 \pm 0.03$ & $0.47 \pm 0.03$ \\
\hline $\mathrm{Na}(\%)$ & $0.08 \pm 0.03$ & $0.11 \pm 0.03$ & $0.13 \pm 0.04$ \\
\hline $\mathrm{Cl}(\%)$ & $0.50 \pm 0.07$ & $0.86 \pm 0.07$ & $1.11 \pm 0.03$ \\
\hline $\mathrm{DCAD}^{4}(\mathrm{mEq} / \mathrm{kg})$ & $+109 \pm 35$ & $-66 \pm 17$ & $-176 \pm 20$ \\
\hline
\end{tabular}

${ }^{1}$ Contains (DM basis) 3.65\% Ca, 0.88\% P, $5.48 \% \mathrm{Mg}, 0.90 \% \mathrm{~K}, 2.34 \% \mathrm{~S}, 1.05 \% \mathrm{Na}, 1.57 \% \mathrm{Cl}$, and (per kg of DM) $724 \mathrm{mg}$ of Zn, $165 \mathrm{mg}$ of Cu, $543 \mathrm{mg}$ of Mn, $9 \mathrm{mg}$ of Se, $16 \mathrm{mg}$ of I, $4 \mathrm{mg}$ of Co, 232,000 IU of vitamin A, 67,000 IU of vitamin $\mathrm{D}_{3}, 3,300 \mathrm{IU}$ of vitamin $\mathrm{E}$, and $750 \mathrm{mg}$ of monensin.

${ }^{2}$ Bio-Chlor (Arm and Hammer Animal Nutrition Inc., Trenton, NJ).

${ }^{3}$ Samples of ingredients were collected weekly and composited each month for chemical analyses. A total of 5 samples of each ingredient were analyzed for chemical composition.

${ }^{4}$ Calculated as $(\mathrm{mEq}$ of $\mathrm{K}+\mathrm{mEq}$ of $\mathrm{Na})-(\mathrm{mEq}$ of $\mathrm{Cl}+\mathrm{mEq}$ of $\mathrm{S})$.

Shoreview, MN) and water. At birth, calves received an intranasal modified-live vaccine against bovine rhinotracheitis and parainfluenza virus-3 (TSV-2, Zoetis, Parsippany-Troy Hills, NJ). Then, at 3 and 5 wk of age, calves were vaccinated with an injectable modified-live vaccine against bovine rhinotracheitis, parainfluenza virus-3, bovine viral diarrhea virus, and bovine respiratory syncytial virus (Bovishield Gold, Zoetis). Bulls were sold after birth, and thus only heifers were kept thereafter $(\mathrm{n}=44)$. Heifers were fed pasteurized milk by bucket at 0600 and $1800 \mathrm{~h}$ until $42 \mathrm{~d}$. Calves were given $6 \mathrm{~L}$ of milk/d in the first $21 \mathrm{~d}$ of life and then $8 \mathrm{~L}$ of milk/d from 21 to $42 \mathrm{~d}$ of life. Milk allotment was reduced to $3 \mathrm{~L} / \mathrm{d}$ before complete weaning at $49 \mathrm{~d}$. Calves were moved to a group pen at $62 \pm 3 \mathrm{~d}$ of age.

\section{Growth and Health Parameters}

Calf BW, hip height, respiration rate, and rectal temperature were recorded at 21 and $42 \mathrm{~d}$ of age. Additionally, BW at $62 \pm 3 \mathrm{~d}, 3 \mathrm{mo}$, and $6 \mathrm{mo}$ of age was recorded. The ADG from birth to $62 \pm 3 \mathrm{~d}$ was calculated. Health scores were determined using the University of Wisconsin-Madison's Calf Health Scoring
Sheet (McGuirk, 2008) at 21 and 42 d of age. Scores were determined by the same person throughout the experiment. Scores were assigned for the presence and severity of nasal and ocular discharge $(0-3 ; 0=$ normal and $3=$ heavy discharge $)$ and cough $(0-3 ; 0=$ none, $1=$ induced, and $3=$ spontaneous cough). The total respiratory scores were calculated by adding the nasal, cough, and ocular scores; if total respiratory score exceeded 4 , then calves required treatment. No calves in the experiment exceed a total respiratory score of 4 . Calves treated for scours at any time point throughout the preweaning period were documented on AfiFarm Dairy Farm Management Software (AfiMilk Ltd., Kibbutz Afikim, Israel) and assigned as 1 if treated or 0 if not treated.

\section{Blood Minerals and Acid-Base Balance}

Blood samples were collected via venipuncture of the jugular vein into 10-mL tubes containing sodium heparin (Vacutainer, Becton Dickinson, Franklin Lakes, NJ) at birth, before colostrum feeding, and at $1(24 \pm 3 \mathrm{~h})$, $2,3,21$, and $42 \mathrm{~d}$ of age. Within 20 min of collection, plasma was separated by centrifugation at $200 \times g$ for 
20 min and stored at $-20^{\circ} \mathrm{C}$ until laboratory analysis. Additional samples of whole blood were collected via venipuncture of the jugular vein at birth and $3 \mathrm{~d}$ of age and analyzed, within 5 min of collection, for $\mathrm{pH}$, partial pressure of carbon dioxide $\left(\mathbf{p C O}_{2}\right)$, partial pressure of oxygen, bicarbonate $\left(\mathbf{H C O}_{3}{ }^{-}\right), \mathrm{Na}, \mathrm{K}$, and ionized $\mathrm{Ca}$ (iCa) concentrations using a handheld biochemical analyzer (CG8+; VetScan iSTAT, Abaxis, Union City, CA). Plasma samples were analyzed for total Ca (tCa) and $\mathrm{Mg}$ concentrations using an atomic absorption spectrophotometer (AAnalyst 200, Perkin-Elmer Inc., Waltham, MA) according to procedures previously described by Martinez et al. (2012). Samples were analyzed in a single run, and intra-assay coefficients of variation $(\mathbf{C V})$ were $6.4 \%$ for $\mathrm{tCa}$ and $4.8 \%$ for $\mathrm{Mg}$.

\section{Energy Metabolism}

Plasma concentrations of nonesterified fatty acids (NEFA) and BHB were measured by colorimetric and enzymatic methods, respectively (kit no. FA115 and RB1007; Randox Laboratories Ltd., Crumlin, UK). The interassay CV for NEFA and BHB were 8.5 and $8.3 \%$, respectively. An autoanalyzer (Technicon Instruments Corp., Chauncey, NY) was used to measure concentrations of plasma glucose (Bran and Luebbe industrial method 339-19; Gochman and Schmitz, 1972). The intra- and interassay CV were 2.2 and $12.7 \%$, respectively.

\section{Efficiency of Ig Absorption}

Colostrum samples, collected 3 times per week during the experiment, and plasma samples, collected $1 \mathrm{~d}$ (24 $\pm 3 \mathrm{~h}$ ) after birth, were used to measure total IgG concentrations by radial immunodiffusion assay (Triple $\mathrm{J}$ Farms, Bellingham, WA) per the manufacturer's protocol. Briefly, plasma and colostrum samples were diluted $1: 2$ and $1: 5$, respectively, in $0.9 \%$ saline to fall within the linear range of the standard curve. The diluted samples were pipetted into the bovine antibovine $\operatorname{IgG}$ antibody plate and incubated for $27 \mathrm{~h}$ in a flat surface protected from light. The diameter of the precipitin ring was measured using a $7 \times$ scale lupe (no. 1975; Peak Optics, GWJ Co., La Quinta, CA) and used to calculate the IgG concentrations. The interassay CV of the radial immunodiffusion averaged $11 \%$. The percentage of apparent efficiency of IgG absorption (\% AEA) of the calves at $1 \mathrm{~d}$ of age was calculated according to Quigley et al. (1998). Colostrum IgG concentrations (g) of the sample closest to birth were used to estimate the IgG intake of individual calves. The colostrum IgG quality and total plasma protein were assessed using a digital refractometer (Milwaukee Instruments, Rocky Mount, NC).

\section{Hematology Analysis}

For the assessment of blood hematology, whole blood was collected via venipuncture of the jugular vein from calves into evacuated tubes containing $\mathrm{K}_{2}$ EDTA (Becton Dickinson) at birth (before colostrum feeding) and at $1,2,3,21$, and $42 \mathrm{~d}$ of age. Samples were carefully mixed, placed on ice, and transported to the laboratory within $2 \mathrm{~h}$ of collection to be analyzed using the Idexx ProCyte Dx analyzer (Idexx Laboratories Inc., Westbrook, ME). The ProCyte Dx analyzer uses laser flow cytometry, optical fluorescence, and laminar flow impedance technologies in combination with chemical reagents that lyse or alter the blood cells to enable the measurement of the complete blood count.

\section{Statistical Analysis}

Continuous data were analyzed by ANOVA with mixed models using the MIXED procedure of SAS (version 9.4; SAS Institute Inc., Cary, NC). The model included the fixed effects of level of DCAD ( -70 or -180 $\mathrm{mEq} / \mathrm{kg}$ ), the feeding durations ( $\mathrm{S}$ or $\mathrm{L}$ ), the sampling time or age of calf (age), and their interactions. The random effect was calf nested within DCAD level and duration. Data from male calves were included only for the analyses of birth BW and gestation length. Body weight at birth, 3 mo, and 6 mo of age and ADG were analyzed using the same model without repeated measures. Normality of residuals and homogeneity of variance were assessed in all models before final analyses. Whenever appropriate, transformation of data was performed to achieve normality or nonparametric tests were performed. Categorical variables were analyzed by logistic regression using the GLIMMIX procedure of SAS fitting binary distribution. Correlation coefficients between blood measures of metabolic acidosis and IgG absorption parameters (e.g., \% AEA, IgG, and $\mathrm{pH}$ ) and between $\mathrm{pH}$ and $\mathrm{pCO}_{2}$ were calculated using the PROC CORR procedure of SAS. All results reported are least squares means \pm the standard error of the mean. Differences with $P \leq 0.05$ were considered statistically significant and $0.05<P \leq 0.10$ were considered tendencies toward significance.

\section{RESULTS}

\section{Growth and Health Parameters}

Dams fed DCAD for the $\mathrm{L}$ duration had shorter $(P$ $=0.02)$ gestation lengths relative to dams fed for the 
S duration (274 vs. $277 \pm 0.85$ d, respectively). Calves born to $\mathrm{L}$ dams weighed less $(P=0.001)$ compared with those born to $\mathrm{S}$ dams (Table 2). When gestation length was included as a covariate in the statistical model for birth BW, there was still a significant difference between the $\mathrm{S}$ and L DCAD durations, in which calves born to $\mathrm{L}$ dams weighed less $(P=0.04)$ compared with calves born to $\mathrm{S}$ dams (40.6 vs. $42.3 \pm 0.7$ $\mathrm{kg}$, respectively). As expected, males were heavier $(P$ $=0.01)$ than females at birth $(42.9$ vs. $39.7 \pm 0.81 \mathrm{~kg}$, respectively), but there were no interactions between sex of the calf, DCAD level, or duration of feeding. There was an interaction $(P=0.01)$ between duration and age of the calves for BW. Calves born to L dams weighed less $(P=0.01)$ at $62 \mathrm{~d}$ compared with calves born to $\mathrm{S}$ dams (Table 2). There were no differences between level of DCAD, duration of feeding, or their interactions for BW at 3 and 6 mo of age $(107 \pm 2.6$ and $201 \pm 5.3 \mathrm{~kg}$, respectively; $P>0.17$ ) or for ADG from birth to $62 \mathrm{~d}$ of age $(0.67 \pm 0.03 \mathrm{~kg}$; average of 4 treatments; $P>0.44$ ). There were no differences $(P>0.92)$ between levels of DCAD, duration of feeding, or their interactions for respiratory scores, and no calves exceeded a score of 4 . There were no differences $(P>0.59)$ between level of DCAD, duration of feeding, or their interactions for the proportion of calves treated for scours; 55, 58, 63, and $50 \%$ of the calves were treated for scours in the $-180 \mathrm{~L},-180 \mathrm{~S},-70 \mathrm{~L}$, and $-70 \mathrm{~S}$ treatments, respectively, through the experiment. There was 1 instance of respiratory problems in the $-70 \mathrm{~L}$ treatment, 1 in the $-70 \mathrm{~S}$ treatment, and 1 in the $-180 \mathrm{~L}$ treatment; thus, they were not analyzed statistically.

\section{Mineral Metabolism}

Whole-blood concentrations of $\mathrm{K}$ and $\mathrm{Na}$ were not affected by DCAD level, duration of feeding, or their interaction (Table 3). There was an effect of age $(P<$ 0.001 ) of the calves for both minerals, in which concentrations of $\mathrm{K}$ increased and those of Na decreased from birth to $3 \mathrm{~d}$ (Table 3). Maternal treatments did not affect circulating $\mathrm{Mg}$, but there was an effect of age in which $\mathrm{Mg}$ concentrations were elevated at birth and at $1 \mathrm{~d}$ of age and decreased thereafter $(P<0.001$; Table $3)$. There was an interaction $(P=0.05)$ between DCAD level and age for iCa, where heifers born to -180 and -70 dams had similar iCa concentrations at birth (1.31 vs. $1.29 \pm 0.02 \mathrm{mM}$ ), but those born to -180 dams had increased iCa concentration at $3 \mathrm{~d}$ of age, whereas those born to -70 dams did not change (1.34 vs. $1.28 \pm$ 0.02 ; Table 3$)$. Heifers born to -180 dams tended $(P=$ $0.10)$ to have greater tCa concentrations compared with those born to -70 dams (3.02 vs. $2.93 \pm 0.03 \mathrm{mmol} / \mathrm{L}$; Table 3). Additionally, tCa concentrations decreased ( $P$ $<0.01)$ with age from $3.02 \mathrm{mmol} / \mathrm{L}$ at birth to $2.87 \pm$ $0.05 \mathrm{mmol} / \mathrm{L}$ at $42 \mathrm{~d}$ of age (Table 3 ).

\section{Acid-Base Balance}

There was an interaction between DCAD level and age for blood $\mathrm{pH}(P=0.01$; Table 4$)$. At birth, heifers born to -180 dams had a less acidic blood $\mathrm{pH}$ at birth compared with those born to -70 dams; however, at $3 \mathrm{~d}$ of age blood $\mathrm{pH}$ did not differ among treatments. There was a significant effect of age $(P<0.001)$ for $\mathrm{HCO}_{3}{ }^{-}$concentrations in which concentrations of

Table 2. Body weight and hip height of calves born to Holstein dams fed diets with 2 levels of negative $\mathrm{DCAD}^{1}(-70 \mathrm{or}-180 \mathrm{mEq} / \mathrm{kg})$ for 2 durations [the last $21 \mathrm{~d}$ prepartum (short, S) or $42 \mathrm{~d}$ prepartum (long, L)] ${ }^{2}$

\begin{tabular}{|c|c|c|c|c|c|c|c|c|c|c|c|}
\hline \multirow[b]{2}{*}{ Item } & \multicolumn{4}{|c|}{ Treatment $^{3}$} & \multirow[b]{2}{*}{ SEM } & \multicolumn{6}{|c|}{$P$-value ${ }^{4}$} \\
\hline & $-70 \mathrm{~S}$ & $-180 \mathrm{~S}$ & $-70 \mathrm{~L}$ & $-180 \mathrm{~L}$ & & Lev & Dur & Age & Lev $\times$ Dur & Lev $\times$ Age & Dur $\times$ Age \\
\hline \multicolumn{12}{|c|}{ BW (kg) } \\
\hline Birth $^{5}$ & 42.5 & 43.3 & 40.7 & 39.3 & 0.81 & 0.80 & 0.001 & & 0.31 & & \\
\hline $21 \mathrm{~d}$ & 53.6 & 54.3 & 53.5 & 49.5 & 2.5 & 0.47 & 0.38 & $<0.001$ & 0.29 & 0.95 & 0.01 \\
\hline $42 \mathrm{~d}$ & 67.7 & 67.5 & 71.2 & 68.2 & & & & & & & \\
\hline $62 \mathrm{~d}$ & 80.7 & 82.3 & 78.4 & 75.1 & & & & & & & \\
\hline $42 \mathrm{~d}$ & 35.2 & 36.1 & 36.21 & 35.4 & & & & & & & \\
\hline $62 \mathrm{~d}$ & 36.8 & 37.4 & 37.1 & 37.0 & & & & & & & \\
\hline
\end{tabular}

${ }^{1}$ Calculated as follows: (mEq of $\mathrm{K}+\mathrm{mEq}$ of $\left.\mathrm{Na}\right)-(\mathrm{mEq}$ of $\mathrm{Cl}+\mathrm{mEq}$ of $\mathrm{S})$.

${ }^{2}$ Data are presented as $\mathrm{LSM} \pm \mathrm{SEM} ; P \leq 0.05$ indicates statistical difference.

${ }^{3} \mathrm{n}=9-12$ calves/treatment.

${ }^{4} \mathrm{Lev}=$ effect of level of negative DCAD ( $\left.-70 \mathrm{vs} .-180 \mathrm{mEq} / \mathrm{kg}\right) ;$ Dur = effect of duration of feeding $(42 \mathrm{vs} .21 \mathrm{~d}) ;$ Age $=$ effect of age at measurement. The triple interaction DCAD Lev $\times$ Dur $\times$ Age did not differ statistically for any of the parameters estimated $(P>0.10)$.

${ }^{5}$ Birth BW includes data from male and female calves. 
COLLAZOS ET AL.

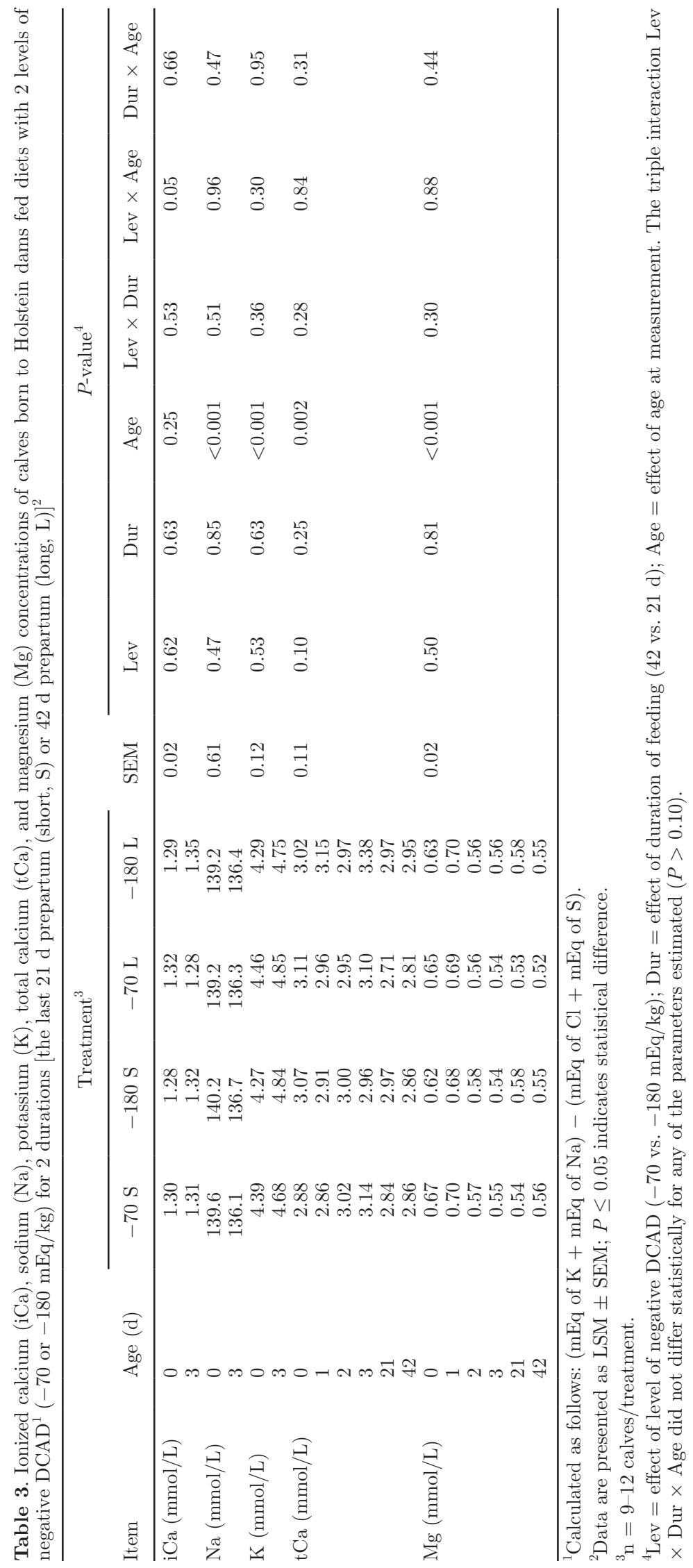


$\mathrm{HCO}_{3}{ }^{-}$increased from birth to $3 \mathrm{~d}$ of age (Table 4). Similar to $\mathrm{pH}$, there was a significant interaction $(P$ $=0.01$ ) between DCAD level and age for $\mathrm{pCO}_{2}$ (Table 4). At birth, heifers born to -180 dams had less $\mathrm{pCO}_{2}$ compared with those born to -70 dams, but at $3 \mathrm{~d}$ of age $\mathrm{pCO}_{2}$ did not differ with level of DCAD.

\section{Energy Metabolism}

There was an interaction $(P=0.04)$ between DCAD level and age for BHB concentrations (Figure 1A). Heifers born to -180 dams had smaller BHB concentrations compared with those born to -70 dams, specifically at 1 and $42 \mathrm{~d}$ of age. Plasma concentration of NEFA tended to be less $(P=0.07)$ in heifers born to -180 dams compared with those born to -70 dams (Figure 1B). At birth, calves had greater $(P<0.001)$ plasma NEFA concentrations compared with later days (Figure 1B). Glucose concentrations did not differ among treatments; however, there was an effect $(P<0.001)$ of age in which glucose concentrations increased markedly from approximately 88 to $135 \mathrm{mg} / \mathrm{dL}$ from birth to $2 \mathrm{~d}$ of age and then gradually decreased to $105 \pm 4.5 \mathrm{mg} /$ $\mathrm{dL}$ at $42 \mathrm{~d}$ of age (Figure $1 \mathrm{C}$ ).

\section{Efficiency of Ig Absorption and Total Protein}

Plasma IgG concentrations at $1 \mathrm{~d}$ of age $(24 \pm 3$ h) did not differ between DCAD level or duration of feeding and averaged $24.8 \pm 2.7 \mathrm{~g} / \mathrm{L}$ (Table 5). Maternal treatments did not influence efficiency of $\mathrm{IgG}$ absorption of the heifers at $1 \mathrm{~d}$ of age, which averaged $33 \%$ (Table 5). Total protein concentrations were not affected by level of maternal DCAD; however, there was an interaction between DCAD duration and age $(P$ $=0.04)$ in which at $3 \mathrm{~d}$ of age heifers born to $\mathrm{L}$ dams had less total protein concentration in blood plasma compared with those born to $\mathrm{S}$ dams (9.2 vs. $9.7 \pm$ 0.15, respectively; Figure 1D).

\section{Correlations Between $\mathrm{pH}$, Measures of $\lg \mathrm{G}$ Absorption, and Blood Gases}

The Pearson correlations between blood $\mathrm{pH}$ at birth with either blood concentration of IgG at $24 \mathrm{~h}(\mathrm{r}=$ $0.07, P=0.74)$ or with $\%$ AEA $(\mathrm{r}=-0.24, P=0.27)$ were not significant (Figure 2A and B). Similarly, the correlations between blood $\mathrm{pH}$ at $24 \mathrm{~h}$ and either blood concentration of $\operatorname{IgG}$ at $24 \mathrm{~h}(\mathrm{r}=0.27, P=0.19)$ or $\%$ AEA $(\mathrm{r}=0.23, P=0.28)$ were not significant (Figure $2 \mathrm{C}$ and $\mathrm{D}$ ). Pearson correlations between blood $\mathrm{pH}$ and $\mathrm{pCO}_{2}$ at birth $(\mathrm{r}=-0.86, P<0.0001 ;$ Figure $3 \mathrm{~A}), 24$ $\mathrm{h}$ of life $(\mathrm{r}=-0.89, P<0.001$; Figure $3 \mathrm{~B})$, and $72 \mathrm{~h}$ of life $(\mathrm{r}=0.88, P<0.001$; Figure $3 \mathrm{C})$ were all significant.

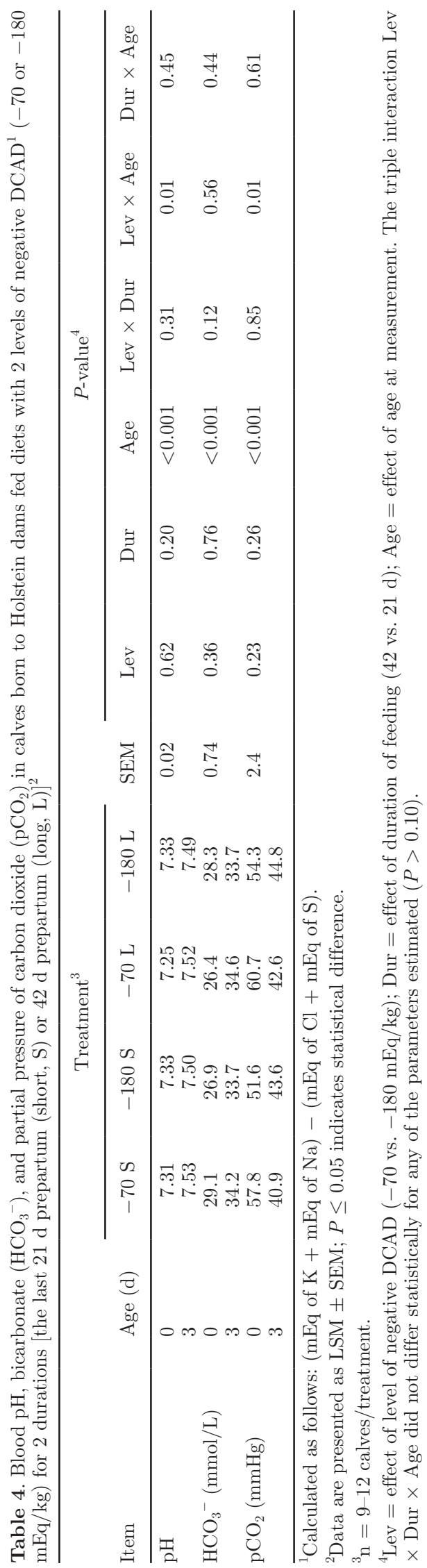

Journal of Dairy Science Vol. 100 No. 12, 2017 
๑ Short, last $21 \mathrm{~d}$

- Long, last $42 \mathrm{~d}$
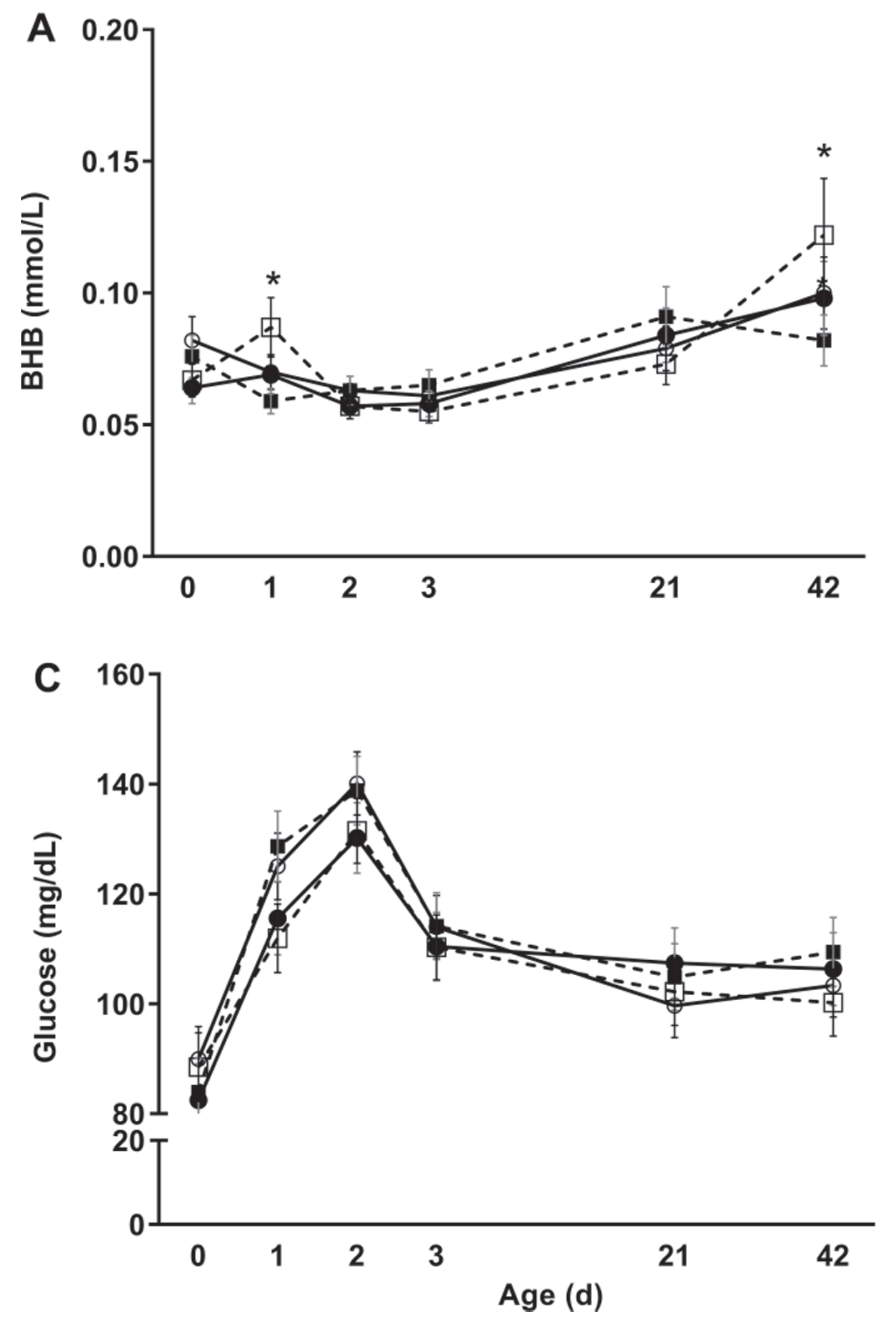

$-\mathbf{m} \cdot-180 \mathrm{mEq} / \mathrm{kg}$ DCAD

$-\square \cdot-70 \mathrm{mEq} / \mathrm{kg}$ DCAD
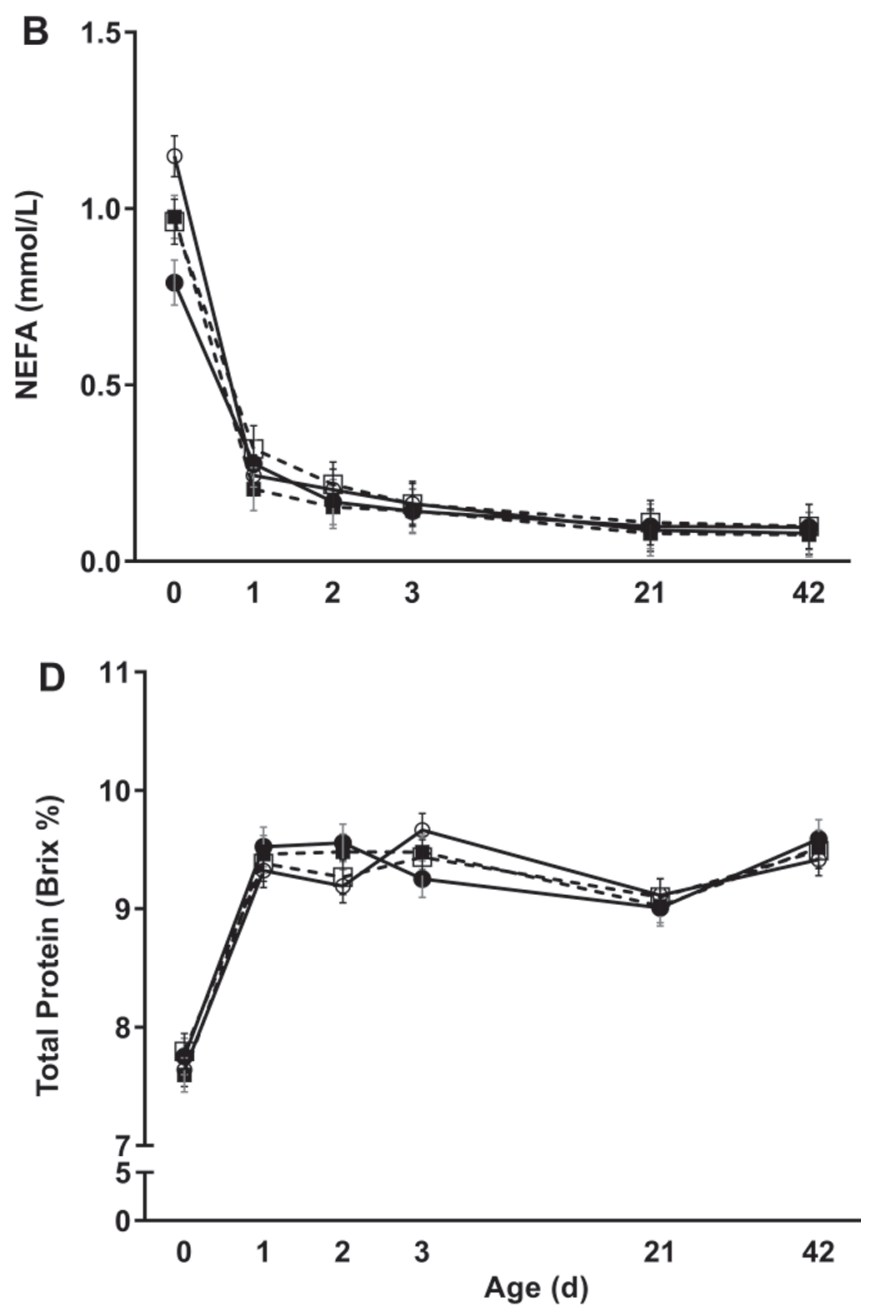

Figure 1. Effects of the level ( -70 vs. $-180 \mathrm{mEq} / \mathrm{kg}$ ) and duration (21 d, short vs. $42 \mathrm{~d}$, long) of feeding maternal diets with negative DCAD during late gestation on circulating concentrations of (A) BHB, (B) nonesterified fatty acids (NEFA), (C) glucose, and (D) total protein in calves $(\mathrm{n}=9-12 /$ treatment $)$ at birth $(0 \mathrm{~h})$ and $24 \mathrm{~h}, 48 \mathrm{~h}, 72 \mathrm{~h}, 3 \mathrm{wk}$, and 6 wk after birth. Calves born to dams fed -180 DCAD had decreased $(P$ $=0.01$ ) BHB concentrations compared with calves born to dams fed -70 DCAD, specifically at 1 and $42 \mathrm{~d}$ of age. Calves born to dams fed -180 DCAD tended to have decreased $(P=0.07)$ NEFA concentrations compared with calves born to dams fed -70 DCAD. Glucose and total protein concentrations were not affected $(P>0.13)$ by maternal treatments. There was a significant age effect $(P<0.001)$ for glucose, NEFA, and total protein. Triple interactions (level $\times$ duration $\times$ age) were not significant $(P>0.10)$. Asterisks $(*)$ denote statistical difference $(P \leq$ 0.05). Error bars indicate SEM.

Table 5. Immunoglobulin G concentration in colostrum and apparent efficiency of IgG absorption in calves born to Holstein dams fed diets with 2 levels of negative $\mathrm{DCAD}^{1}\left(-70\right.$ or $-180 \mathrm{mEq} / \mathrm{kg}$ ) for 2 durations [the last $21 \mathrm{~d}$ prepartum (short, S) or $42 \mathrm{~d}$ prepartum (long, L)] ${ }^{2}$

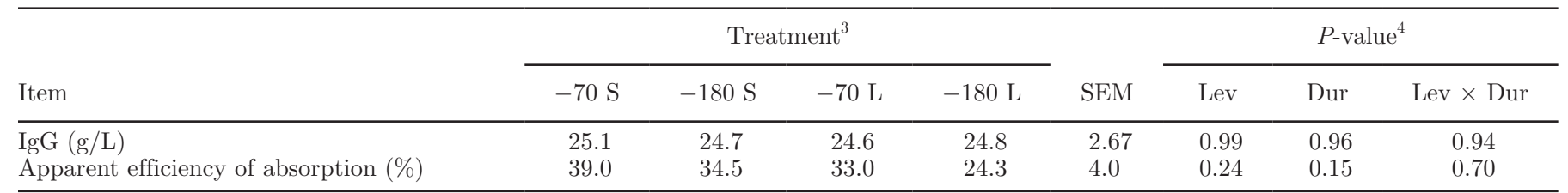

${ }^{1}$ Calculated as follows: $(\mathrm{mEq}$ of $\mathrm{K}+\mathrm{mEq}$ of $\mathrm{Na})-(\mathrm{mEq}$ of $\mathrm{Cl}+\mathrm{mEq}$ of $\mathrm{S})$.

${ }^{2}$ Data are presented as LSM $\pm \mathrm{SEM} ; P \leq 0.05$ indicates statistical difference.

${ }^{3} \mathrm{n}=9-12$ calves/treatment.

${ }^{4} \mathrm{Lev}=$ effect of level of negative DCAD ( -70 vs. $\left.-180 \mathrm{mEq} / \mathrm{kg}\right) ;$ Dur = effect of duration of feeding $(42 \mathrm{vs} .21 \mathrm{~d})$. 


\section{Blood Hematology}

There were no effects $(P>0.11)$ of DCAD level, duration of feeding, or their interactions for the concentration of red blood cells or hematocrit; however, age affected $(P<0.001)$ the red blood cell count and hematocrit (Table 6). Hemoglobin concentrations did not differ $(P>0.12)$ with maternal treatments (Table $6)$. Reticulocyte counts peaked at $3 \mathrm{~d}$ of age and then drastically decreased $(P<0.001)$ at 21 and $42 \mathrm{~d}$, but there were no differences among treatments (Table 6). There was an interaction $(P=0.05)$ between duration of feeding and age of the calf for platelet counts. Calves born to L dams had decreased platelet counts compared with calves born to $\mathrm{S}$ dams, specifically at birth (255 vs. $389 \pm 33 \times 10^{3} / \mu$ L; Table 6$)$.

Overall, white blood cell counts increased $(P<0.001)$ from birth to $42 \mathrm{~d}$ of age, but there were no differences
$(P>0.39)$ due to maternal treatments. The concentrations of neutrophils in blood initially increased from birth to $2 \mathrm{~d}$ of age and then slightly decreased after that, whereas lymphocyte counts decreased from birth to $2 \mathrm{~d}$ of age and then sharply increased in the blood of calves (Table 7). Although total and individual leukocyte counts in blood did not differ with treatment, calves born to $\mathrm{L}$ dams had a smaller $(P=0.02)$ proportion of neutrophils but greater $(P=0.03)$ proportion of lymphocytes in blood compared with calves from $\mathrm{S}$ dams (Table 7). There were no differences between maternal treatments for monocyte, basophil, and eosinophil counts or the percentages. Notably, the counts for monocytes, basophils, and eosinophils in the blood of the calves were less than $1 \times 10^{3} / \mu \mathrm{L}$ at all time points evaluated. However, the patterns of changes in the relative proportion of these cells to the total leukocytes with age were not the same. The percentage
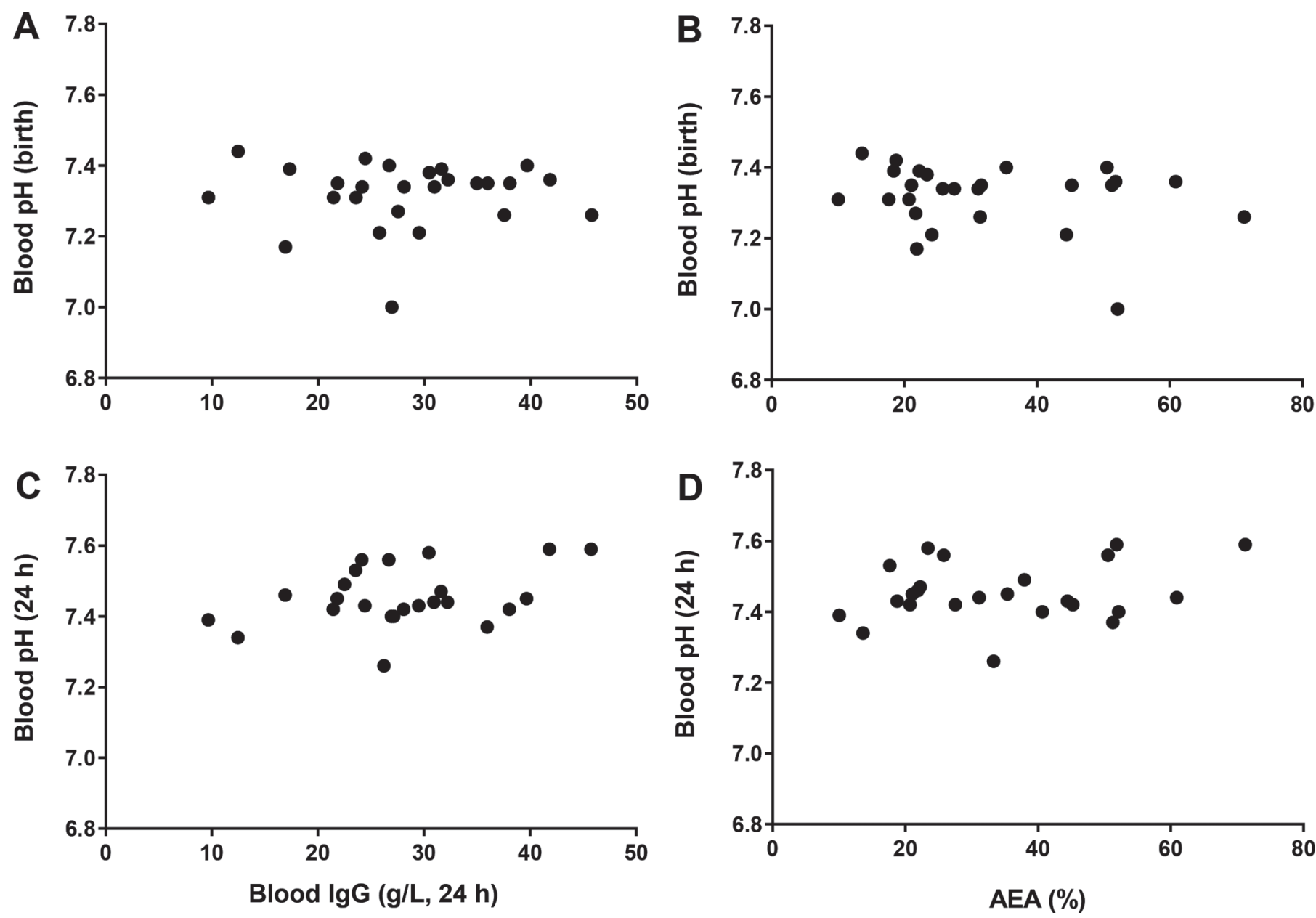

Figure 2. Correlations between blood metabolic acidosis and parameters of IgG absorption in calves born to dams fed diets with negative DCAD during late gestation. Pearson correlation between blood $\mathrm{pH}$ at birth and $(\mathrm{A})$ blood concentration of $\operatorname{IgG}$ at $24 \mathrm{~h}(\mathrm{r}=0.07, P=0.74)$ or (B) apparent efficiency of IgG absorption (\% AEA; $\mathrm{r}=-0.24, P=0.27)$. Pearson correlation between blood $\mathrm{pH}$ at $24 \mathrm{~h}$ of age and $(\mathrm{C})$ blood concentration of IgG at $24 \mathrm{~h}(\mathrm{r}=0.27, P=0.19)$ or $(\mathrm{D}) \%$ AEA $(\mathrm{r}=0.23, P=0.28)$. Statistical difference was considered when $P \leq 0.05$. 

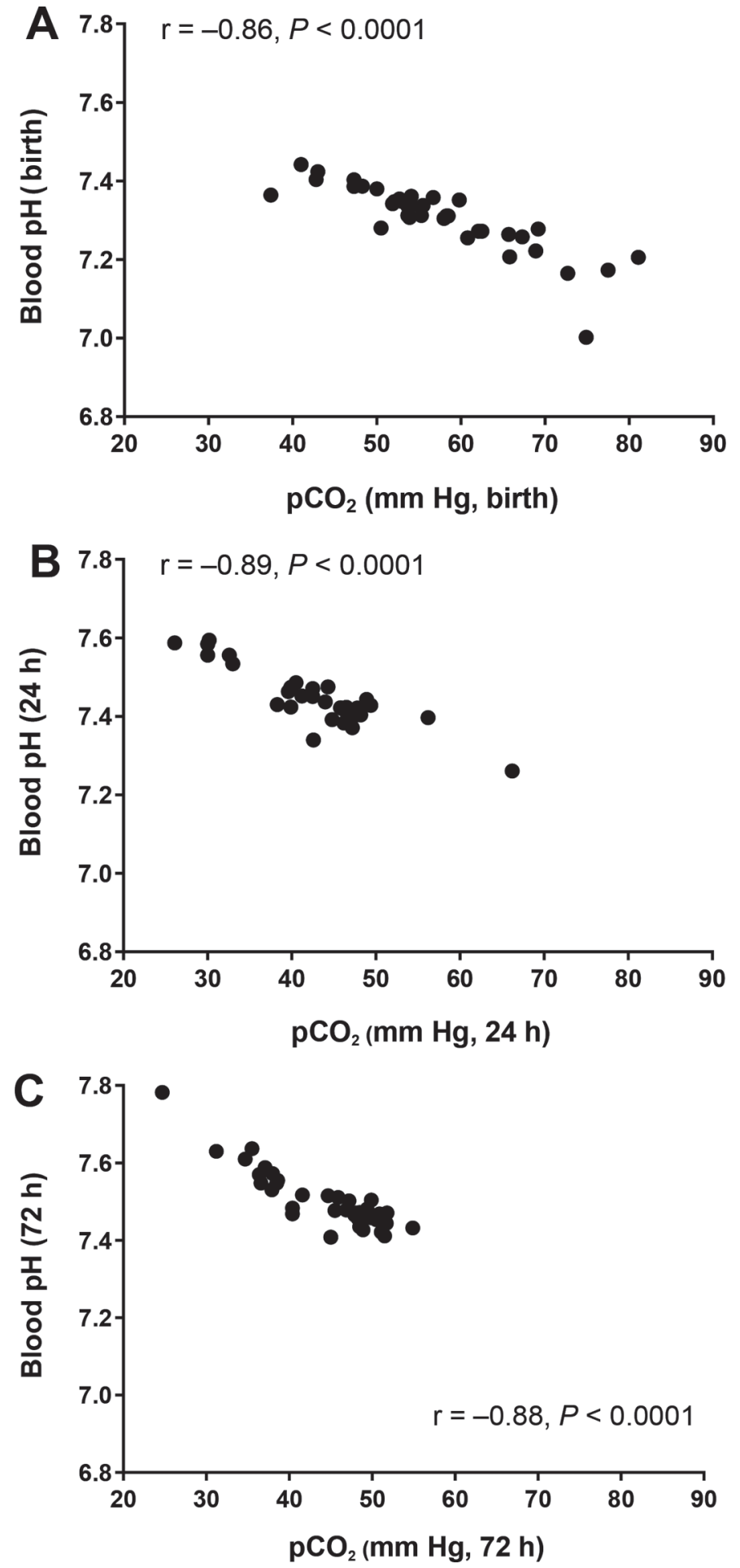

Figure 3. Correlations between blood acid-base balance variable $(\mathrm{pH})$ and blood gases $\left(\mathrm{pCO}_{2}\right)$ at (A) birth, (B) $24 \mathrm{~h}$ of age, and (C) 72 $\mathrm{h}$ of age in calves born to dams fed diets with negative DCAD during late gestation. Pearson correlation between blood $\mathrm{pH}$ at birth and $(\mathrm{A})$ blood concentration of $\mathrm{pCO}_{2}$ at birth $(\mathrm{r}=-0.86, P<0.0001)$, (B) 24 $\mathrm{h}$ of age $(\mathrm{r}=-0.89, P<0.0001)$, and $(\mathrm{C}) 72 \mathrm{~h}$ of age $(\mathrm{r}=-0.88, P<$ $0.0001)$. Statistical difference was considered when $P \leq 0.05$. of eosinophils was less than $3 \%$ at all time points; the percentage of basophils was less than $3 \%$ at birth and at 1,3 , and $21 \mathrm{~d}$ of age, and it decreased to less than $0.5 \%$ at $42 \mathrm{~d}$ of age; and the percentage of monocytes was less than $2 \%$ at birth and at 1,3 , and $21 \mathrm{~d}$ of age, and it then sharply increased to $10 \%$ at $42 \mathrm{~d}$ of age.

\section{DISCUSSION}

It is known that reducing the level of DCAD to negative values by feeding acidogenic diets in the last weeks prepartum induces a compensated metabolic acidosis in cows (Goff, 2008), but the optimal combination of duration of feeding and level of DCAD remains unknown. Limited experiments have addressed whether the maternal acid-base status can influence the developing offspring. Our results show that extending the duration of feeding acidogenic diets to prepartum cows from the typically recommended $21 \mathrm{~d}$ to $42 \mathrm{~d}$ reduced the calf's BW at birth from 42.9 to $40.0 \mathrm{~kg}$, which might suggest reduced nutrient transfer or incorporation into fetal tissues prenatally. It is important to note that the differences in BW at birth were observed even when gestation length was included as a covariate in the statistical analysis. Contrary to the present experiment, Weich et al. (2013) did not find differences in the birth weight of calves from cows fed a diet with $-160 \mathrm{mEq} /$ $\mathrm{kg}$ with feeding extended from 21 to $42 \mathrm{~d}$ prepartum and compared with calves from cows fed a diet with $+120 \mathrm{mEq} / \mathrm{kg}$ for $42 \mathrm{~d}$.

Small changes in $\mathrm{pH}$ may cause significant derangement in fetal function and outcome (Omo-Aghoja, 2014). Rodents exposed to chronic metabolic acidosis had impaired growth (May et al., 1986). Extending the feeding of diets with negative DCAD reduced gestation length by approximately $3 \mathrm{~d}$ compared with cows given a shorter duration. The 3-d difference may seem negligible, but it has been shown that gestation lengths of $268,273,284$, and $290 \mathrm{~d}$ yield probabilities of calf mortality of 5.5, 3.9, 3.1, and 3.6\%, respectively (Johanson and Berger, 2003). Altered stress hormones (i.e., glucocorticoids) by acidosis have been reported in humans and rodents (May et al., 1986; Sicuro et al., 1998). The prolonged acidosis of the dam could have stimulated fetal maturation of the hypothalamus, triggering the release of corticotropin-releasing factor, resulting in parturition and, therefore, shorter gestation length. Indeed, pregnant women suffering from acidosis, based on blood $\mathrm{pH}$ less than the normal range of 7.40 to 7.50 during the last trimester of gestation, have increased risk of preterm labor (shorter than 35 wk of gestation; Frise et al., 2013). Cord acidosis during preterm delivery (24.0-33.6 wk of gestation) was associated with 
NEGATIVE DIETARY CATION-ANION DIFFERENCES PREPARTUM

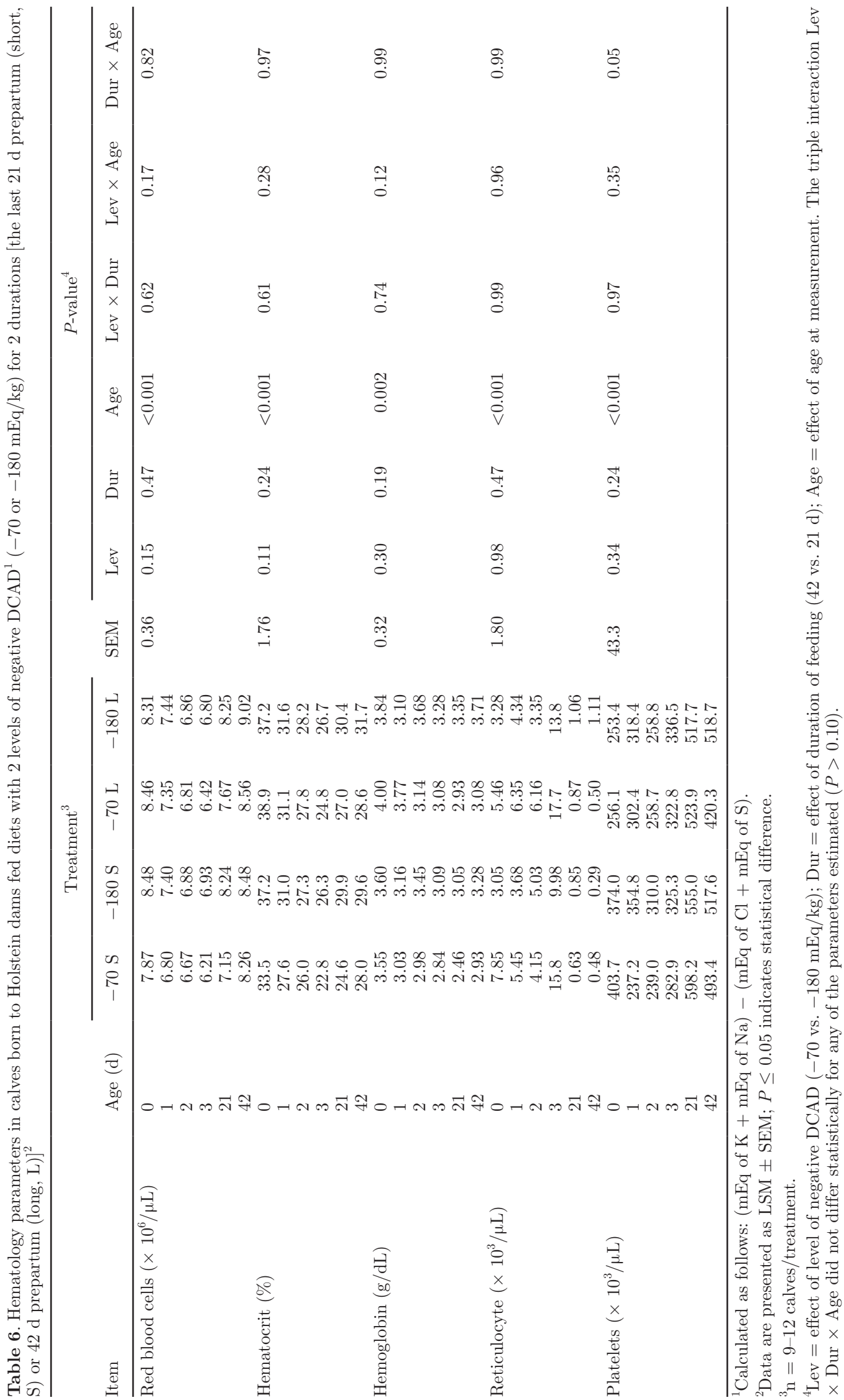


COLLAZOS ET AL.

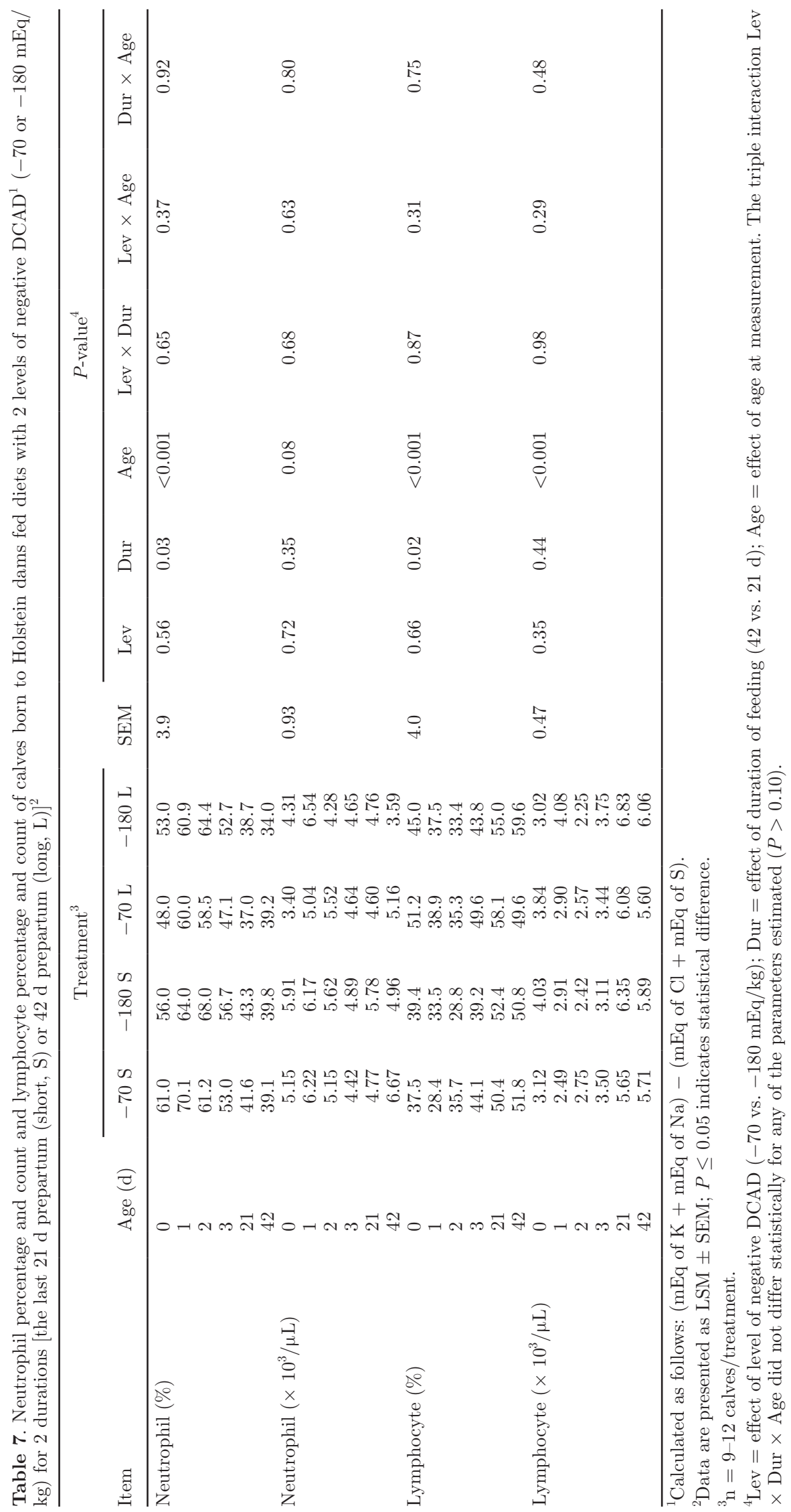


12-fold increased odds of fetal distress (Andreani et al., 2007). However, the exact mechanism by which maternal acidosis triggers parturition is not completely understood. One possible explanation for the lighter BW at $\mathrm{d} 62$ of heifers born to dams fed a diet with negative DCAD for an extended duration is that the extended exposure to a more acidogenic diet led to metabolic acidosis, and the subsequent transfer of those changes to the environment in utero could have altered signaling pathways involved in the stress response (i.e., cortisol or prolactin). Consequently, these heifers would be less able than their counterparts to adapt to the stressors of gradual weaning and thus gained less weight. Thus, the extended duration of feeding maternal diets with negative DCAD, but not the level of maternal DCAD, seem to have a significant effect on calf BW during early life; however, these differences are not observed later in life.

It has been suggested that $\mathrm{Ca}$ ions are actively pumped across the placenta from mother to fetus but that the fetus is capable of independently controlling its own Ca homeostasis (Delivoria-Papadopoulos et al., 1967; Care, 1989). Specifically, in sheep, pigs, and guinea pigs, it has been shown that increased $\mathrm{Ca}$ in the pregnant dam does not have a significant effect on fetal plasma Ca concentrations (Bawden and Wolkoff, 1967; Greeson et al., 1968; Abbas et al., 1987). Despite the differences observed the last $14 \mathrm{~d}$ prepartum in concentrations of iCa in the dams fed -180 DCAD prepartum compared with the dams fed -70 DCAD prepartum (1.282 vs. $1.252 \mathrm{~m} M$ for -180 and $-70 \mathrm{DCAD}$, respectively; Lopera et al., 2016), iCa concentrations at birth in the heifers did not differ with dam treatment. Interestingly, it was observed that at $3 \mathrm{~d}$ of age, heifers born to -180 DCAD dams had increased concentrations of $\mathrm{iCa}$ relative to birth, whereas in heifers born to -70 DCAD dams those concentrations remained unaltered between birth and $3 \mathrm{~d}$ of age. Calves begin to depend on absorption of $\mathrm{Ca}$ through the intestines and skeletal Ca stores at approximately $3 \mathrm{~d}$ of age (Kovacs and Kronenberg, 1997). Whether the origin of the increased iCa in heifer calves born to -180 DCAD dams was a result of increased absorption efficiency or an increase in feed intake is unknown because colostrum intake was not recorded after the first feeding. Additionally, milk and grain intakes were not recorded. It is possible that the more acidic maternal environment affected the ability of Ca to efficiently bind to albumin differently. An in vitro study observed that an acidic environment decreases Ca binding to proteins, mainly albumin, and increases iCa (Wang et al., 2002). In this experiment, heifers born to dams fed -70 DCAD had a more exacerbated metabolic acidosis but less concentrations of free iCa. However, on d 0 the percentage of tCa that is in the ionized form was slightly higher compared with d 3 and compared with that in calves born to dams fed -180 DCAD (43.8 and $41.5 \%$ for $-70 \mathrm{~d} 0$ and 3 , respectively; 42.2 and $42.3 \%$ for $-180 \mathrm{~d} 0$ and 3 , respectively).

Metabolic acidosis is characterized by imbalances in the $\mathrm{HCO}_{3}{ }^{-}$buffer system, whereas respiratory acidosis is characterized by imbalances in $\mathrm{pCO}_{2}$; both imbalances can cause blood $\mathrm{pH}$ to fall below a normal range of 7.40 to 7.50 in cows. In the companion experiment (Lopera et al., 2016), dams fed the -180 DCAD experienced a compensated metabolic acidosis based on smaller urinary $\mathrm{pH}(-180 \mathrm{DCAD}=5.46$ vs. $-70 \mathrm{DCAD}$ $=6.38), \mathrm{pCO}_{2}(-180 \mathrm{DCAD}=38.9$ vs. $-70 \mathrm{DCAD}=$ $40.1 \mathrm{mmHg})$, and $\mathrm{HCO}_{3}{ }^{-}(-180 \mathrm{DCAD}=23.2$ vs. -70 DCAD $=26.0 \mathrm{mM}$ ). On the contrary, heifers born to -70 DCAD dams had a more evident metabolic acidosis at birth because they had a more acidic blood $\mathrm{pH}$ and their $\mathrm{pCO}_{2}$ was greater compared with those born to dams fed the -180 DCAD. All heifers were under some degree of metabolic acidosis at birth. The exposure of the dam to an acidogenic diet fed for a longer period of time, which resulted in a more pronounced metabolic acidosis, made their calves more capable of exhibiting a compensatory response after birth in their acid-base balance. Thus, these calves were able to better or more rapidly adapt during the transition from the intrauterine to extrauterine environment. Interestingly, at $3 \mathrm{~d}$ of age all the calves achieved blood $\mathrm{pH}, \mathrm{pCO}_{2}$ and $\mathrm{HCO}_{3}{ }^{-}$ values that no longer reflected metabolic acidosis.

According to Boyd (1989), calves with a mean $\mathrm{pH}$ of 7.24, mean $\mathrm{pCO}_{2}$ of $67.4 \mathrm{mmHg}$, and mean $\mathrm{HCO}_{3}{ }^{-}$of $28.3 \mathrm{mmol} / \mathrm{L}$ are diagnosed with mixed respiratory or metabolic acidosis. Acidosis may be common at birth when blood $\mathrm{pH}$ and plasma $\mathrm{HCO}_{3}{ }^{-}$concentrations are reduced and the $\mathrm{pCO}_{2}$ is increased compared with other stages of life. With increasing age, $\mathrm{pCO}_{2}$ decreases and blood $\mathrm{pH}$ increases as a result of improved respiratory function and adapting to the extrauterine environment (Moore, 1969). The negative correlation between $\mathrm{pH}$ and $\mathrm{pCO}_{2}$, in which $\mathrm{pCO}_{2}$ increased as calf blood $\mathrm{pH}$ became more acidic, is opposed to what typically is observed in adult animals, in which a reduction in blood $\mathrm{pH}$ induces compensatory mechanisms, one of which is the increase in $\mathrm{CO}_{2}$ exhaled, which typically reduces $\mathrm{pCO}_{2}$. These data suggest that calves in the first $3 \mathrm{~d}$ of life do not seem to be able to compensate for the metabolic acidosis through respiratory mechanisms likely caused by the hypoventilation during the first days of life, thereby resulting in hypercapnia. These data do not allow for inferences of when the respiratory mechanism becomes active to compensate for the metabolic acidosis because samples were not collected after $3 \mathrm{~d}$ of age. It is clear that hypoventilation occurred when blood was collected after birth as $\mathrm{pCO}_{2}$ decreased 
from 0 to $3 \mathrm{~d}$ of age; however, it is possible that even by $3 \mathrm{~d}$ of age, lung capacity to compensate for the metabolic acidosis remains less than optimal compared with that in adult animals. The inability for respiratory compensation likely justifies the much smaller blood $\mathrm{pH}$ in calves at birth compared with the results from their dams that averaged $7.416 \pm 0.005$ and $7.383 \pm$ 0.005 for -70 and $-180 \mathrm{DCAD}$, respectively, before calving (Lopera et al., 2016). Overall, neither the more acidogenic diet nor the extended duration of feeding negative DCAD prepartum to dams induced a noticeable uncompensated metabolic acidosis in their calves.

Diarrhea has been linked to metabolic acidosis (Kasari, 1999); however, in this experiment the percentage of calves that had to be treated for diarrhea during the preweaning period did not differ with treatments. Furthermore, we did not observe differences in calves' blood electrolytes, $\mathrm{Na}$ and $\mathrm{K}$, which could be indicative of gastrointestinal tract inflammation and loss of buffers (Sobiech et al., 2013). However, electrolytes were assessed only during the first $3 \mathrm{~d}$ of life, so they might not reflect what happens when calves develop diarrhea, which typically occurs at 5 to $14 \mathrm{~d}$ of life. There were only 2 cases of respiratory problems, which occurred in maternal treatments $-70 \mathrm{~S}$ and $-180 \mathrm{~L}$, and 1 case of pneumonia, which occurred in maternal treatment -70 $\mathrm{L}$, but because of the low incidence, these postnatal observations were not analyzed statistically. Feeding acidogenic diets, by reducing the DCAD from +130 to $-130 \mathrm{mEq} / \mathrm{kg}$, does not influence colostrum yield or nutrient content of $\operatorname{IgG}$ concentration [N. Martinez (University of Florida, Gainesville), R. Rodney (SBScibus, Camden, NSW, Australia), E. Block (Church and Dwight Co. Inc., Princeton, NJ), L. L. Hernandez (University of Wisconsin, Madison), C. D. Nelson (University of Florida, Gainesville), I. J. Lean (University of Sydney, Camden, NSW, Australia), and J. E. P. Santos (University of Florida, Gainesville), , unpublished data], and reducing the DCAD from -70 to $-180 \mathrm{mEq} / \mathrm{kg}$ did not alter colostrum yield or composition (Lopera et al., 2016). However, pooled colostrum was fed to the newborn calves to minimize any minor differences in nutrient content to test the concept of changes in calf acid-base status on IgG absorption. Regardless of the transient acidosis observed at birth in calves born to dams fed a $-70 \mathrm{mEq} / \mathrm{kg}$ DCAD diet, the plasma concentrations of $\operatorname{IgG}$ and the apparent efficiency of $\operatorname{IgG}$ absorption in the calves at $1 \mathrm{~d}$ of age was not different among treatments. Indeed, no relationship between serum IgG or IgG absorption with blood $\mathrm{pH}$ at birth or at $24 \mathrm{~h}$ was observed herein. Boyd (1989) reported a negative correlation between extremely acidotic calves (with blood $\mathrm{pH}<7.15$ ) and reduced colostrum intake, which led to decreased IgG concentrations in the calves; however, similarly to us they did not find any correlations between moderately acidotic calves or calves with normal $\mathrm{pH}$ and their IgG concentrations. Likewise, Drewry et al. (1999) reported that calves born with increased or reduced $\mathrm{pCO}_{2}$ achieved adequate plasma IgG concentrations and efficiency of IgG absorption if fed high-quality colostrum at birth.

Calves from dams fed the -180 DCAD had reduced circulating concentrations of both BHB and NEFA without alterations in circulating glucose concentrations during the preweaning period. Blood samples were drawn before the colostrum feeding, which could explain the relatively high concentrations of NEFA at birth. In a young calf, the major source of BHB is the rumen. Thus, concentrations of BHB are indicators of rumen development with increasing calf starter or grain intake and rumen digestion (Quigley et al., 1991), whereas NEFA concentrations could be a consequence of less starter consumption in the -180 calves. However, grain intake was not recoded in this experiment to confirm this. The greater concentrations of NEFA in calves born to -70 dams could have been a response to increased feed consumption or increased efficiency of absorption of nutrients. Nevertheless, despite subtle differences seen in BHB and NEFA concentrations, the concentrations in blood were within normal ranges in all calves.

The complete blood count of the calves was not greatly affected by maternal dietary treatments fed prepartum. However, as expected, both erythrocytes and leukocytes were affected by the age of the calf as they actively develop immunological maturation (Reece, 2009). At birth, calves born to dams fed the negative DCAD for an extended duration had lower platelet counts compared with calves born to dams fed the negative DCAD for a shorter duration. Platelets are necessary for the coagulation process; therefore, decreased platelets are associated with failure of clot retraction. However, platelet blood indices such as mean platelet volume and platelet hematocrit did not suggest susceptibility of illness in the calves with lower platelet counts. When the negative DCAD duration was extended, the percentage of neutrophils decreased and the percentage of lymphocytes increased. In addition, monocyte, basophil, and eosinophil counts and their respective percentages changed as the calves underwent immunological maturation, but similarly, these parameters were not affected by the duration or level of maternal DCAD and were all within normal ranges described for Holstein calves (Mohri et al., 2007). Regardless of these slight hematological differences, the health and morbidity of the calves was not compromised. 


\section{CONCLUSIONS}

Extending the duration of feeding acidogenic salts to the dam from the typically recommended $21 \mathrm{~d}$ to $42 \mathrm{~d}$ prepartum decreased the offspring's birth weight and reduced the dam's gestation length. The acid-base status and the mineral and energy metabolism of the calf were affected exclusively by the negative level of DCAD in the maternal diet. The metabolic acidosis in calves born to -70 DCAD dams was observed only at birth. Calves recovered completely by $3 \mathrm{~d}$ of age, suggesting that it was a transient compensated acidosis. The more acidic calves were less efficient in expelling the excess of $\mathrm{pCO}_{2}$, but no relationship with measures of IgG absorption or efficiency was observed. Maternal treatments did not affect morbidity and mortality of calves, and the hematology parameters evaluated were within the normal ranges of healthy calves. Indeed, the lag in the growth observed at birth in calves born to -180 DCAD dams was compensated for by 3 and 6 mo of age. Further research is needed to evaluate the longterm performance of heifers during their first lactation.

\section{ACKNOWLEDGMENTS}

This study was supported by a grant from the Southeast Milk Check-Off Program (Belleview, FL) awarded to J. Laporta.

\section{REFERENCES}

Abbas, S. K., I. W. Caple, A. D. Care, N. Loveridge, T. J. Martin, D. W. Pickard, and C. Rodda. 1987. The role of the parathyroid glands in fetal calcium homeostasis in the sheep. J. Phys. (London) $386: 27$.

Andreani, M., A. Locatelli, F. Assi, S. Consonni, S. Malguzzi, G. Paterlini, and A. Ghidini. 2007. Predictors of umbilical artery acidosis in preterm delivery. Am. J. Obstet. Gynecol. 197:303.

Bawden, J. W., and A. S. Wolkoff. 1967. Fetal blood calcium responses to maternal calcium infusion in sheep. Am. J. Obstet. Gynecol. 99:55-60.

Besser, T. E., and C. C. Gay. 1994. The importance of colostrum to the health of the neonatal calf. Vet. Clin. North Am. Food Anim. Pract. 10:107-117.

Boyd, J. W. 1989. Relationships between acid-base balance, serum composition and colostrum absorption in newborn calves. Br. Vet. J. 145:249-256.

Care, A. D. 1989. Development of endocrine pathways in the regulation of calcium homeostasis. Baillieres Clin. Endocrinol. Metab. $3: 671-688$.

Charbonneau, E., D. Pellerin, and G. R. Oetzel. 2006. Impact of lowering dietary cation-anion difference in nonlactating dairy cows: A meta-analysis. J. Dairy Sci. 89:537-548.

Corah, L. R., T. G. Dunn, and C. C. Kaltenbach. 1975. Influence of prepartum nutrition on the reproductive performance of beef females and the performance of their progeny. J. Anim. Sci. 41:819 824.

Curtis, C. R., H. N. Erb, C. J. Sniffen, R. D. Smith, P. A. Powers, M. C. Smith, M. E. White, R. B. Hillman, and E. J. Pearson. 1983. Association of parturient hypocalcemia with eight periparturient disorders in Holstein cows. J. Am. Vet. Med. Assoc. 183:559-561.
Delivoria-Papadopoulos, M., F. C. Battaglia, P. D. Bruns, and G. Meschia. 1967. Total, protein-bound, and ultrafilterable calcium in maternal and fetal plasmas. Am. J. Physiol. 213:363-366.

Drewry, J. J., J. D. Quigley III, D. R. Geiser, and M. G. Welborn. 1999. Effect of high arterial carbon dioxide tension on efficiency of immunoglobulin G absorption in calves. Am. J. Vet. Res. 60:609-614.

Du, M., J. Tong, J. Zhao, K. R. Underwood, M. Zhu, S. P. Ford, and P. W. Nathanielsz. 2010. Fetal programming of skeletal muscle development in ruminant animals. J. Anim. Sci. 88:E51-E60.

Frise, C. J., L. Mackillop, K. Joash, and C. Williamson. 2013. Starvation ketoacidosis in pregnancy. Eur. J. Obstet. Gynecol. Reprod. Biol. 167:1-7.

Gao, F., Y. C. Liu, Z. H. Zhang, C. Z. Zhang, H. W. Su, and S. L. Li. 2012. Effect of prepartum maternal energy density on the growth performance, immunity, and antioxidation capability of neonatal calves. J. Dairy Sci. 95:4510-4518.

Gochman, N., and J. M. Schmitz. 1972. Application of a new peroxide indicator reaction to the specific, automated determination of glucose with glucose oxidase. Clin. Chem. 18:943-950.

Goff, J. P. 2008. The monitoring, prevention, and treatment of milk fever and subclinical hypocalcemia in dairy cows. Vet. J. 176:50-57.

Greeson, C. D., E. G. Crawford, and J. W. Bawden. 1968. Fetal blood calcium response to maternal hypercalcemia in guinea pigs. J. Dent. Res. 47:447-449.

Horst, R. L., J. P. Goff, T. A. Reinhardt, and D. R. Buxton. 1997. Strategies for preventing milk fever in dairy cattle. J. Dairy Sci. 80:1269-1280.

Huber, T. L., R. C. Wilson, A. J. Stattelman, and D. D. Goetsch. 1981. Effect of hypocalcemia on motility of the ruminant stomach. Am. J. Vet. Res. 42:1488-1490.

Johanson, J. M., and P. J. Berger. 2003. Birth weight as a predictor of calving ease and perinatal mortality in Holstein cattle. J. Dairy Sci. 86:3745-3755.

Kasari, T. R. 1999. Metabolic acidosis in calves. Vet. Clin. North Am. Food Anim. Pract. 15:473-486.

Kovacs, C. S., and H. M. Kronenberg. 1997. Maternal-fetal calcium and bone metabolism during pregnancy, puerperium, and lactation. Endocr. Rev. 18:832-872.

Lopera, C., R. Zimpel, F. R. Lopes Jr., W. G. Ortiz, B. N. Faria, M. R. Carvalho, A. Vieira Neto, M. L. Gambarini, E. Block, C. D. Nelson, and J. E. P. Santos. 2016. Effect of level of dietary cation-anion difference and duration of prepartum feeding on calcium and measures of acid-base status in transition cows. J. Anim. Sci. 94(E-Suppl. 5):736. (Abstr.)

Martinez, N., C. A. Risco, F. S. Lima, R. S. Bisinotto, L. F. Greco, E. S. Ribeiro, and J. E. P. Santos. 2012. Evaluation of peripartal calcium status, energetic profile, and neutrophil function in dairy cows at low or high risk of developing uterine disease. J. Dairy Sci. 95:7158-7172.

May, R. C., R. A. Kelly, and W. E. Mitch. 1986. Metabolic acidosis stimulates protein degradation in rat muscle by a glucocorticoiddependent mechanism. J. Clin. Invest. 77:614-621.

McGuirk, S. M. 2008. Disease management of dairy calves and heifers. Vet. Clin. Food. Anim. 24:139-153.

Mohri, M., K. Sharifi, and S. Eidi. 2007. Hematology and serum biochemistry of Holstein dairy calves: Age related changes and comparison with blood composition in adults. Res. Vet. Sci. 83:30-39.

Moore, W. E. 1969. Acid-base and electrolyte changes in normal calves during the neonatal period. Am. J. Vet. Res. 30:1133-1138.

Morrill, K. M., S. P. Marston, N. L. Whitehouse, M. E. Van Amburgh, C. G. Schwab, D. M. Haines, and P. S. Erickson. 2010. Anionic salts in the prepartum diet and addition of sodium bicarbonate to colostrum replacer, and their effects on immunoglobulin G absorption in the neonate. J. Dairy Sci. 93:2067-2075.

NAHMS (National Animal Health Monitoring System). 2014. Dairy Cattle Management Practices in the United States, 2014. NAHMS, Washington, DC.

Oetzel, G. R. 1988. Parturient paresis and hypocalcemia in ruminant livestock. Vet. Clin. North Am. Food Anim. Pract. 4:351-364. 
Omo-Aghoja, L. 2014. Maternal and fetal acid-base chemistry: A major determinant of perinatal outcome. Ann. Med. Health Sci. Res. $4: 8-17$.

Quigley, J. D., J. J. Drewry, and K. R. Martin. 1998. Estimation of plasma volume in Holstein and Jersey calves. J. Dairy Sci. 81:1308-1312.

Quigley, J. D., L. A. Caldwell, G. D. Sinks, and R. N. Heitmann. 1991. Changes in blood glucose, nonesterified fatty acids, and ketones in response to weaning and feed intake in young calves. J. Dairy Sci. 74:250-257.

Quigley, R., and M. Baum. 2004. Neonatal acid base balance and disturbances. Semin. Perinatol. 28:97-102.

Reece, W. O. 2009. Functional Anatomy and Physiology of Domestic Animals. 4th ed. Wiley-Blackwell, Ames, IA

Reinhardt, T. A., J. D. Lippolis, B. J. McCluskey, J. P. Goff, and R. L. Horst. 2011. Prevalence of subclinical hypocalcemia in dairy herds. Vet. J. 188:122-124.
Sicuro, A., K. Mahlbacher, H. N. Hulter, and R. Krapf. 1998. Effect of growth hormone on renal and systemic acid-base homeostasis in humans. Am. J. Physiol. 274:F650-F657.

Sobiech, P., W. Rekawek, M. Ali, R. Targonski, K. Zarczynska, A. Snarska, and A. Stopyra. 2013. Changes in blood acid-base balance parameters and coagulation profile during diarrhea in calves. Pol. J. Vet. Sci. 16:543-549.

Wang, S., E. H. Mcdonnell, F. A. Sedor, and J. G. Toffaletti. 2002. pH effects on measurements of ionized calcium and ionized magnesium in blood. Arch. Pathol. Lab. Med. 126:947-950.

Weich, W., E. Block, and N. B. Litherland. 2013. Extended negative dietary cation-anion difference feeding does not negatively affect postpartum performance of multiparous dairy cows. J. Dairy Sci. 96:5780-5792. 